\title{
Phenolic Hydrogen Abstraction by the Triplet Excited State of Thiochromanone: A Laser Flash Photolysis Study
}

\author{
Alessandra M. Ribeiro, ${ }^{a}$ Ada Ruth Bertoti ${ }^{b}$ and José Carlos Netto-Ferreira ${ }^{*, a, b}$ \\ ${ }^{a}$ Departamento de Química, Instituto de Ciências Exatas, Universidade Federal Rural do Rio de \\ Janeiro, 23851-970 Seropédica-RJ, Brazil \\ ${ }^{b}$ Instituto de Química, Universidade Federal da Bahia, Campus de Ondina, \\ 40170-490 Salvador-BA, Brazil
}

\begin{abstract}
O estado excitado triplete de cetonas pode oxidar substratos biológicos acarretando danos a diversas biomoléculas como aminoácidos, nucleosídeos e mesmo DNA. Como parte de nossos estudos acerca da interação entre carbonilas e fenóis, foi investigada a reatividade do estado excitado triplete de tiocromanona (1) frente a fenóis, em acetonitrila, empregando a técnica de fotólise por pulso de laser de nanossegundo. As constantes de velocidade de supressão obtidas variaram de $(1,1 \pm 0,1) \times 10^{8} \mathrm{~L} \mathrm{~mol}^{-1} \mathrm{~s}^{-1}$ (4-cianofenol) a $(5,8 \pm 1,0) \times 10^{9} \mathrm{~L} \mathrm{~mol}^{-1} \mathrm{~s}^{-1}$ (hidroquinona). Um gráfico de Hammett para a reação do triplete de $\mathbf{1}$ com uma série de fenóis contendo substituintes polares resultou em uma constante de reação $\rho=-0,90$. Este valor negativo para a constante de reação $\rho$ está plenamente de acordo com um mecanismo envolvendo uma transferência acoplada elétron/ próton no processo de transferência de hidrogênio do fenol para a carbonila triplete.
\end{abstract}

Triplet ketones are known to oxidize biological substrates which can lead to damage of several biomolecules such as amino acids, nucleosides and DNA. As part of our systematic study on the interaction between carbonyl compounds and phenols, the triplet reactivity of thiochromanone (1) towards substituted phenols, in acetonitrile, was investigated employing the laser flash photolysis technique. The quenching rate constants ranged from $(1.1 \pm 0.1) \times 10^{8} \mathrm{~L} \mathrm{~mol}^{-1} \mathrm{~s}^{-1}$ (4-cyanophenol) to $(5.8 \pm 1.0) \times 10^{9} \mathrm{~L} \mathrm{~mol}^{-1} \mathrm{~s}^{-1}$ (hydroquinone). A Hammett plot for the reaction of triplet 1 with phenols containing polar substituents resulted in a reaction constant $\rho=-0.90$. This negative value observed for the reaction constant $\rho$ is in accord with a mechanism in which the hydrogen transfer from phenols to the triplet carbonyl involves a coupled electron/proton transfer.

Keywords: thiochromanone, laser flash photolysis, triplet excited state, hydrogen donors

\section{Introduction}

In the last few years the phenolic hydrogen abstraction by carbonyl compounds in the triplet excited state has been extensively studied employing experimental and theoretical methods. ${ }^{1-16}$ The mechanism for this process is now well established and involves the initial formation of a hydrogen-bonded exciplex in the triplet excited state, followed by electron transfer and, subsequently, an ultrafast proton transfer. ${ }^{49-16}$ DFT calculations clearly showed that for the triplet complex (exciplex) ketone-phenol the hydrogen transfer is predominantly occurring. ${ }^{8}$ The very fast quenching rate constants of triplet carbonyls towards phenols is consequence of both the low reduction potential

*e-mail: jcnetto@ufrrj.br of the former as well as the low oxidation potential of the later. ${ }^{4,16}$ Experimentally, this coupled electron/proton transfer mechanism ultimately results in the formation of the ketyl-aryloxyl radical pair.

Triplet ketones are known to oxidize biological substrates such as amino acids, nucleosides and DNA. Due to this, topical or systemic administration of drugs containing the carbonyl chromophore can lead to sever sideeffects upon exposure to sunlight. ${ }^{17}$ This photosensitization process involves direct interaction between the triplet excited state of the sensitizer (the triplet carbonyl) and the biological substrate through the formation of an encounter complex. This species leads to an electron transfer reaction followed by a proton transfer, resulting in the formation of the corresponding radical pair sensitizer/ biological substrate with the consequent damage of several 
biomolecules ${ }^{18-21}$ and, for the DNA case, this process can be responsible for photogenotoxicity. ${ }^{22-25}$ Of special importance is the effect of triplet carbonyl compounds on the photoxidative process of tyrosine and tryptophan, nucleic acid constituents containing a phenol or an indole group, respectively, since this type of reaction can result in high photoallergic activity when several drugs containing the carbonyl group are employed. ${ }^{26-28}$

Thiochromanone derivatives have broad biological activity including antibacterial ${ }^{29}$ and antifungal activity against three Candida species, three Cryptococcus strains, Torulopsis glabrata and Trichosporon cutaneum, which are important pathogens to man and cause a variety of chronic superficial and systemic diseases. ${ }^{30}$ More recently, ${ }^{31}$ it has been demonstrated that several 3 -substituted thiochromanones also show several other antifungal activity.

The ground state absorption spectrum of thiochromanone, in acetonitrile, shows bands in the UV $(\lambda=264,286 \mathrm{~nm})$ and in the visible region $(\lambda=348 \mathrm{~nm})$ of the electromagnetic spectrum. Its phosphorescence spectrum, in 2-methyltetrahydrofuran at $77 \mathrm{~K}$, is relatively intense and shows very little vibrational progression, as expected for $\pi \pi^{*}$ aromatic ketones ${ }^{32}$ and already reported in the literature..$^{33}$ This phosphorescence spectrum shows maxima at 438 and $470 \mathrm{~nm}$ and from the emission at $438 \mathrm{~nm}(0-0$ band $)$ a triplet energy of $65.3 \mathrm{kcal} \mathrm{mol}^{-1}$ could be calculated. ${ }^{33}$

To the best of our knowledge, the only study that has been reported so far relative to the photoreactivity of thiochromanone deals with its photodehydrogenation in methanol leading to 4 -thiochromone. ${ }^{34}$ In the present work we show results concerning the photochemical reactivity of the triplet excited sate of thiochromanone (1) towards phenol and its derivatives containing polar substituents, employing the laser flash photolysis technique.<smiles>O=C1CCSc2ccccc21</smiles>

1

\section{Experimental}

\section{Materials}

Acetonitrile (spectroscopic grade, VETEC) was employed as received. Thiochromanone, $\beta$-carotene, 2-propanol, 1,4-cyclohexadiene, phenol, 3-chlorophenol, 4-chlorophenol, 4-fluorophenol, 4-bromophenol, 4-cyanophenol, 4-tert-butylphenol, hydroquinone, and resorcinol, all from Aldrich, were used as received.

\section{Nanosecond laser flash photolysis}

Samples were irradiated with the $3^{\text {rd }}$ harmonic of Nd-YAG Surelite laser $\left(\lambda_{\text {exc }}=355 \mathrm{~nm}, c a\right.$. 4-6 ns, e $\geq 40 \mathrm{~mJ} /$ pulse), and employing a detection system from Luzchem (Mini-system model mLPF112). Sample concentration ( $c a .1 \mathrm{mmol} \mathrm{L}^{-1}$, in acetonitrile) resulted in an absorbance of ca.0.3 at the excitation wavelength. Stock solutions for the quenchers were prepared in acetonitrile. Quenching procedure involved the addition of microliters of stock solution of the quencher to the sample contained in a Suprasil quartz cell of $10 \mathrm{~mm} \times 10 \mathrm{~mm}$. Samples were deaerated for $30 \mathrm{~min}$ before irradiation by using oxygenfree nitrogen.

\section{Results and Discussion}

Laser excitation $(\lambda=355 \mathrm{~nm})$ of a deoxygenated solution of thiochromanone (1), in acetonitrile, resulted in the formation of a transient showing absorption bands at $\lambda_{\max }=420,480,540$ and $580 \mathrm{~nm}$ (Figure 1A) and a lifetime $\left(\tau_{\mathrm{T}}\right)$ of $1.6 \mu$ s (Figure 1B). This transient was readily quenched by $\beta$-carotene, a well-known triplet acceptor $\left(\mathrm{E}_{\mathrm{T}}=19 \mathrm{kcal} \mathrm{mol}^{-1} ; \Phi_{\mathrm{isc}}=0\right),{ }^{35,36}$ for which we obtained a quenching rate constant $\left(\mathrm{k}_{\mathrm{q}}\right)$, in acetonitrile, of $(1.1 \pm 0.1) \times 10^{10} \mathrm{~L} \mathrm{~mol}^{-1} \mathrm{~cm}^{-1}$. The quenching process followed equation $1:^{37}$

$\mathrm{k}_{\mathrm{obs}}=\mathrm{k}_{\mathrm{o}}+\mathrm{k}_{\mathrm{q}}[\mathrm{Q}]$

where: $\mathrm{k}_{\mathrm{o}}$ is the triplet decay rate constant in the absence of quencher, $\mathrm{k}_{\mathrm{q}}$ is the triplet decay rate constant in the presence of the quencher and $[\mathrm{Q}]$ is the quencher concentration in $\mathrm{mol} \mathrm{L} \mathrm{L}^{-1}$.

The $\pi \pi^{*}$ character for the thiochromanone triplet state ${ }^{18}$ was further confirmed by laser flash photolysis experiments employing hydrogen donors such as 2-propanol and 1,4-cyclohexadiene, in acetonitrile. Attempted quenching of 1 by 2-propanol did not result in any observable decrease in its triplet lifetime, even at a 2-propanol concentration of up to $1.0 \mathrm{~mol} \mathrm{~L}^{-1}$. This lead us to estimate an upper limit of $10^{5} \mathrm{~L} \mathrm{~mol}^{-1} \mathrm{~s}^{-1}$ for this quenching rate constant. On the other hand, when quenching experiments were performed with the very efficient hydrogen donor 1,4-cyclohexadiene, a rate constant of $(7.3 \pm 0.1) \times 10^{6} \mathrm{~L} \mathrm{~mol}^{-1} \mathrm{~s}^{-1}$ was obtained. For comparison, hydrogen abstraction rate constants for triplet aromatic ketones of $\mathrm{n} \pi *$ character from 1,4-cyclohexadiene 

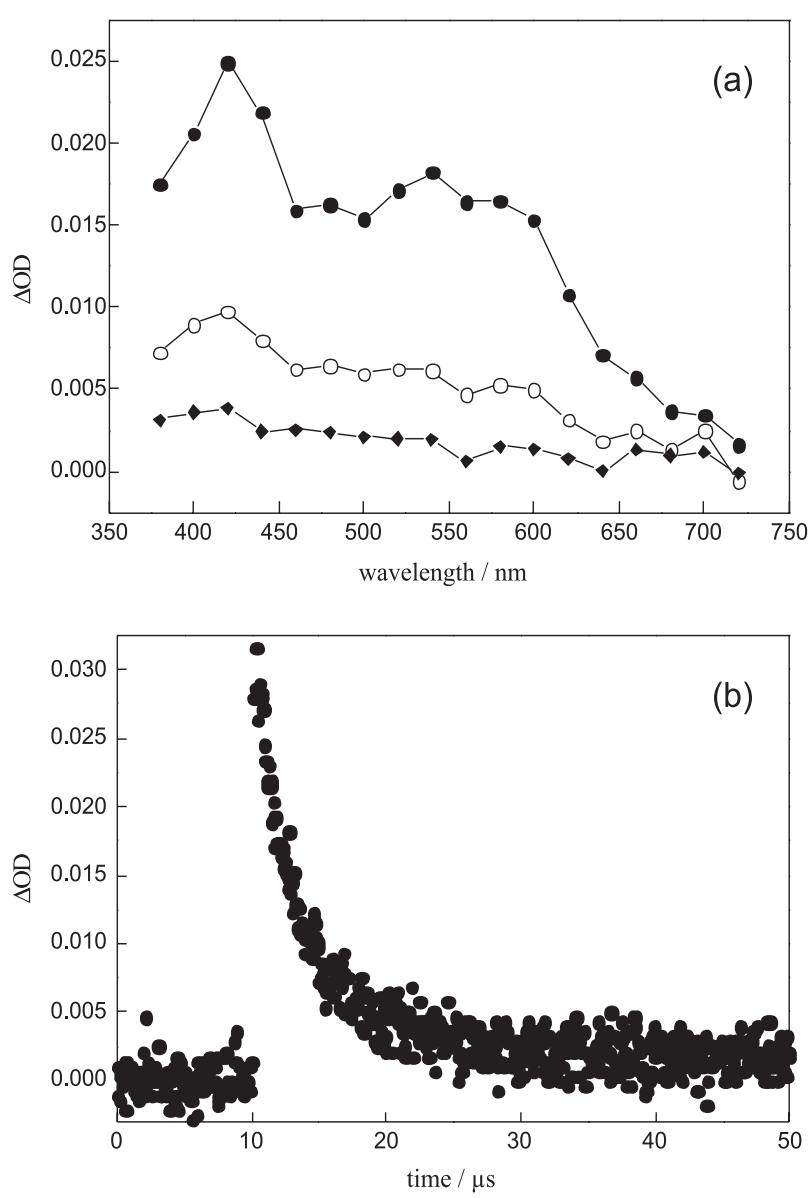

Figure 1. A: Triplet-triplet absorption spectra for thiochromanone (1), in acetonitrile, recorded $1.1(\bullet), 14.3(\square)$ and $27.3 \mu$ s ( $\bullet$ ) after the laser pulse. B: decay for the transient generated as in graph A and monitored at $440 \mathrm{~nm}$.

are in the order of $10^{8} \mathrm{~L} \mathrm{~mol}^{-1} \mathrm{~s}^{-1}, 38$ whereas for $\pi \pi^{*}$ ketones ${ }^{6}$ $\mathrm{k}_{\mathrm{q}}$ ca. $10^{6} \mathrm{~L} \mathrm{~mol}^{-1} \mathrm{~s}^{-1}$.

Linear Stern-Volmer plots (Figure 2) employing equation 1 were obtained from quenching studies of thiochromanone triplet by phenols containing polar substituents (Table 1). A linear Hammett plot (Figure 3), employing the rate constants listed in Table 1 and following equation 2 , resulted in a value for the reaction constant of $\rho=-0.90(r=0.835)$, similar to those obtained for other aromatic ketones or $\alpha$-diketones.

$\log \mathrm{k}_{\mathrm{q}}^{\mathrm{x}} / \mathrm{k}_{\mathrm{q}}^{\mathrm{H}}=\sigma^{+} \rho$

where: $\mathrm{k}_{\mathrm{q}}{ }_{\mathrm{q}}^{\mathrm{X}}$ is the quenching rate constant for a substituted phenol, $\mathrm{k}_{\mathrm{q}}^{\mathrm{H}}$ is the quenching rate constant for phenol, $\sigma^{+}$is a Hammett constant, which depends solely on the nature and position of the substituent, and $\rho$ is the reaction constant, which depends on the reaction under investigation and the conditions under which it takes place.

Thus, for acenaphthenone a value of $\rho=-1.5$ was obtained, ${ }^{1}$ whereas for the $\alpha$-diketones acenaphtheno- quinone, ${ }^{1}$ 1,2-aceanthrylenedione, ${ }^{3}$ and 1,2-diketopyracene ${ }^{4}$ values of $-1.48 ;-1.04$ and -0.90 , respectively, were observed.

In all cases, the proposed mechanism involves the intermediacy of a hydrogen-bonded exciplex between the carbonyl triplet and the phenol. Since the partially protonated triplet is more easily reduced by the partially ionized phenol, the hydrogen-bonding interaction is responsible for reducing the threshold for electron transfer from phenol to triplet ketone. After exciplex formation, the net hydrogen-atom abstraction occurs in the form of an initial electron transfer followed by a fast proton transfer (a coupled electron/ proton transfer mechanism). It is worth to note that the triplet state basicity as well as the reduction potential of the carbonyl group play a very important role in the quenching by the hydrogen-bonded exciplex mechanism Therefore, the enhanced basicity of the carbonyl triplet having $\pi \pi^{*}$ configuration results in a more favorable hydrogen transfer when compared to that of the $\mathrm{n}, \pi^{*}$ state.

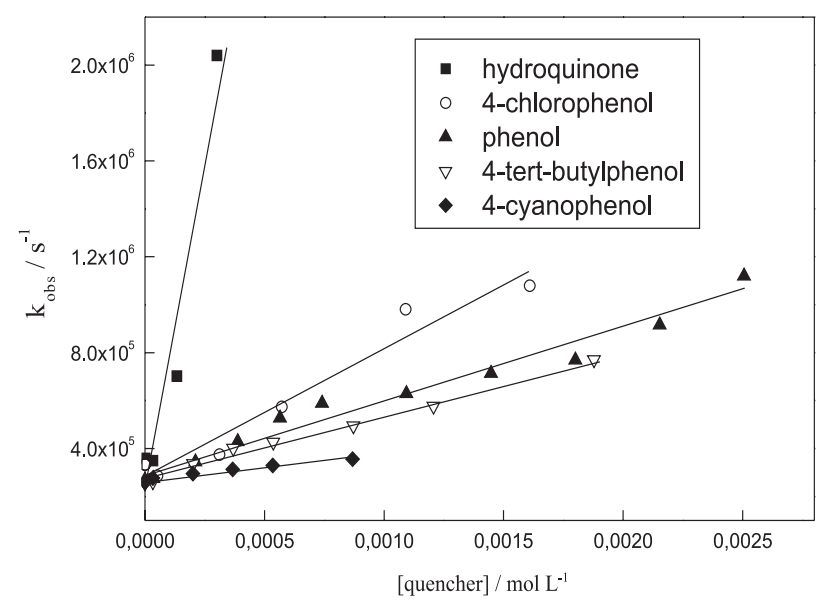

Figure 2. Quenching plots for the triplet excited state of thiochromanone (1) by several phenols, in acetonitrile. $\lambda_{\text {exc }}=355 \mathrm{~nm} ; \lambda_{\text {mon }}=440 \mathrm{~nm}$.

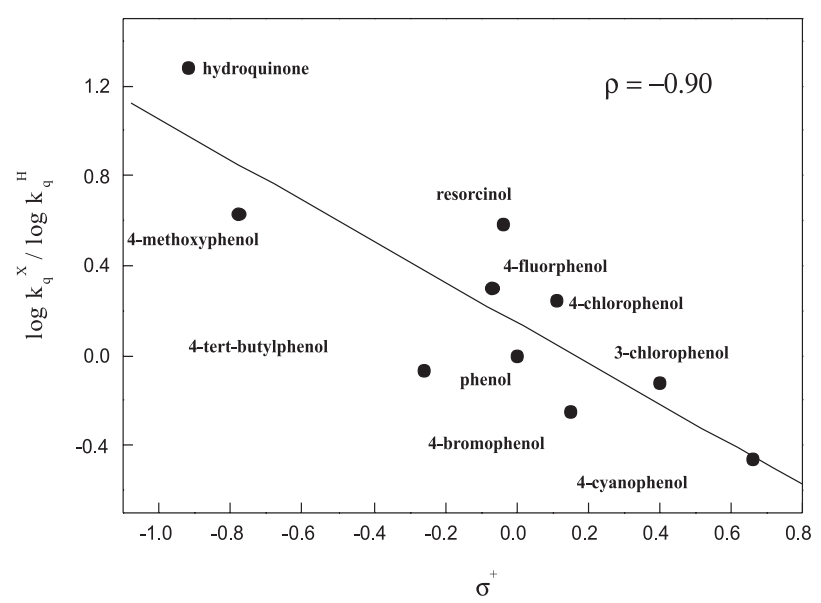

Figure 3. Hammett plot for the hydrogen abstraction reaction of triplet 1 by phenols, in acetonitrile $(\mathrm{R}=0.835)$. 
Table 1. Second order quenching rate constants for thiochromanone (1), in acetonitrile

\begin{tabular}{ll}
\hline Quencher & $\mathrm{k}_{\mathrm{q}} /\left(\mathrm{L} \mathrm{mol}^{-1} \mathrm{~s}^{-1}\right)$ \\
\hline Phenol & $(3.0 \pm 0.2) \times 10^{8}$ \\
3-Chlorophenol & $(2.3 \pm 0.2) \times 10^{8}$ \\
4-Chlorophenol & $(5.3 \pm 0.6) \times 10^{8}$ \\
4-Bromophenol & $(1.7 \pm 0.2) \times 10^{8}$ \\
4-Fluorophenol & $(6.1 \pm 0.4) \times 10^{8}$ \\
4-Methoxyphenol & $(1.3 \pm 0.2) \times 10^{9}$ \\
4-Cyanophenol & $(1.1 \pm 0.1) \times 10^{8}$ \\
4-terc-Butylphenol & $(2.6 \pm 0.1) \times 10^{8}$ \\
Hydroquinone & $(5.8 \pm 1.0) \times 10^{9}$ \\
Resorcinol & $(1.2 \pm 0.1) \times 10^{9}$ \\
\hline
\end{tabular}

The Hammett equation ${ }^{39,40}$ expresses a general quantitative relation between the nature of a given substituent and the reactivity of the reaction center, with the validity of equation 2 being restricted to substituents in the meta- and para-positions of the benzene ring. The reaction constant $(\rho)$ measures the susceptibility of the reaction to the influence of the substituent. Based on $\rho$ values, the transition state characteristic with respect to a developing charge can be obtained. For $\rho>1$, a negative charge is built in the transition state, whereas for $\rho<0$ the reaction develops a positive charge in the transition state. Thus, the negative values for $\rho$ in the hydrogen abstraction reaction of triplet ketones from phenols containing polar substituents cited above are fully in accord with the proposed mechanism for this reaction, independently of<smiles>OC1=CCSc2ccccc21</smiles>

2

the character of their excited state. This mechanism, shown in Scheme 1, involves an initial electron transfer from the phenol to the excited ketone, through an intermediate exciplex, followed by an ultrafast proton transfer, which ultimately results in the formation of the radical pair ketyl/ phenoxyl. ${ }^{1-8}$ In support to this mechanism, Figure 4 shows a representative spectrum obtained after laser irradiation of a deoxygenated solution of thiochromanone (1) in the presence of $1.4 \times 10^{-3} \mathrm{~mol} \mathrm{~L}^{-1}$ of 4-methoxyphenol, in

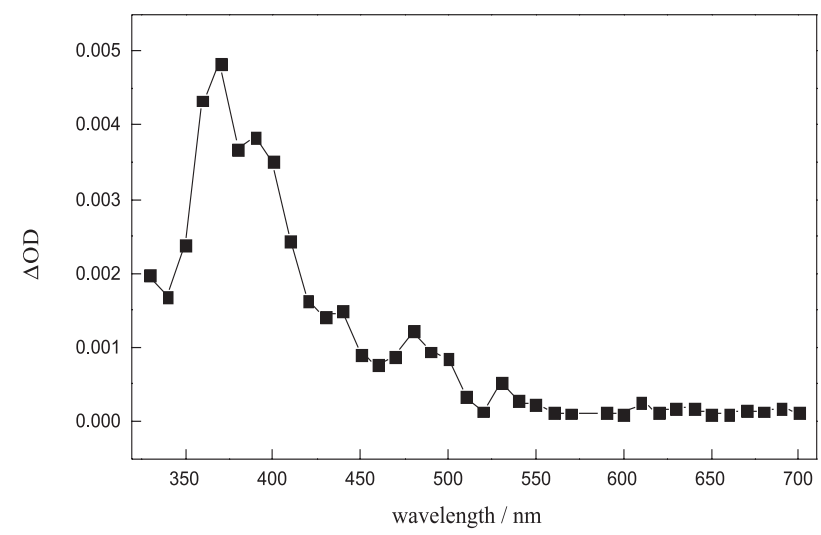

Figure 4. Absorption spectrum for the transients generated upon laser excitation of thiochromanone in the presence of $1.4 \times 10^{-3} \mathrm{~mol} \mathrm{~L}^{-1}$ of 4-methoxyphenol, in acetonitrile, recorded $13 \mu$ s after the laser pulse.<smiles>O=C1CCSc2ccccc2C1=O</smiles>

Scheme 1. 
acetonitrile. In this spectrum the absorptions relative to triplet 1 were substituted for new ones in the $340-440 \mathrm{~nm}$ region, which can be associated to a mixture of the ketyl radical 2 derived from the thiochromanone triplet, as well as to the 4-methoxyphenoxyl radical, which shows absorption at $405 \mathrm{~nm}^{41}$ (Scheme 1). Formation of the radical pair aryloxyl/ketyl was found for all phenols employed in this work.

\section{Conclusions}

In conclusion, it was demonstrated by laser irradiation of thiochromanone (1), in acetonitrile, the formation and characterization of its triplet excited state. Absolute rate constants were measured for the phenolic hydrogen abstraction by this triplet, from which a Hammett plot could be obtained. The negative value observed for the reaction constant $\rho(-0.90)$ is in complete accordance with the proposed mechanism for this type of reaction, which involves a coupled electron/proton transfer.

\section{Acknowledgments}

Financial support from Fundação de Amparo à Pesquisa do Estado da Bahia (FAPESB) and Financiadora de Estudos e Projetos (FINEP) are gratefully acknowledged. We thank Prof. Cristina Maria Quintella for making available the laser flash photolysis facilities at the Universidade Federal da Bahia. A. M. R. thanks Coordenação de Aperfeiçoamento do Pessoal do Ensino Superior (CAPES) for a graduate fellowship.A. R. B. thanks Conselho Nancional de Desenvolvimento Científico e Tecnológico (CNPq) for a graduate fellowship. J. C. N.-F. thanks CNPq/FAPESB for a Visiting Professor fellowship at the Universidade Federal da Bahia.

\section{References}

1. de Lucas, N. C.; Netto-Ferreira, J. C.; J. Photochem. Photobiol., A 1998, 116, 203.

2. Silva, M. T.; Netto-Ferreira, J. C.; J. Photochem. Photobiol., A 2004, 162, 225.

3. Serra, A. C. S.; de Lucas, N. C.; Netto-Ferreira, J. C.; J. Braz. Chem. Soc. 2004, 15, 481.

4. de Lucas, N. C.; Correa, R. J.; Albuquerque, A. C. C.; Firme, C. L.; Garden, S. J.; Bertoti, A. R.; Netto-Ferreira, J. C.; J. Phys. Chem. A 2007, 111, 1117.

5. Netto-Ferreira, J. C.; Bernardes, B.; Ferreira, A. B. B.; Miranda, M. A.; Photochem. Photobiol. Sci. 2008, 7, 467.

6. Netto-Ferreira, J. C.; Lhiaubet-Vallet, V.; Bernardes, B.; Ferreira, A. B. B.; Miranda, M. A.; Phys. Chem. Chem. Phys. 2008, 10, 6645 .
7. Netto-Ferreira, J. C.; Lhiaubet-Vallet, V.; Bernardes, B.; Ferreira, A. B. B.; Miranda, M. A.; Photochem. Photobiol. 2009, 85, 153.

8. de Lucas, N. C.; Elias, M. M.; Firme, C. L.; Correa, R. J.; Garden, S. J.; Netto-Ferreira, J. C.; Nicodem, D. E.; J. Photochem. Photobiol., A 2009, 201, 1.

9. Pérez-Prieto, J.; Boscá, F.; Galian, R. E.; Lahoz, A.; Domingo, L. R.; Miranda, M. A.; J. Org. Chem. 2003, 68, 5104.

10. Das, P. K.; Encinas, M. V.; Scaiano, J. C.; J. Am. Chem. Soc. 1981, 103, 4154.

11. Turro, N. J.; Engel, R.; J. Am. Chem. Soc. 1969, 91, 7113.

12. Biczók, L.; Bérces, T.; Linschitz, H.; J. Am. Chem. Soc. 1997, 119, 11071.

13. Leigh, W. J.; Lathioor, E. C.; St Pierre, M. J.; J. Am. Chem. Soc. 1996, 118, 12339.

14. Miranda, M. A.; Lahoz, A.; Boscá, F.; Metni, M. R.; Abdelouahab, F. B.; Castell, J. V.; Pérez-Prieto, J.; Chem. Commun. 2000, 2257.

15. Miranda, M. A.; Lahoz, A.; Matínez-Mañez, R.; Boscá, F.; Castell, J. V.; Pérez-Prieto, J.; J. Am. Chem. Soc. 1999, 121, 11569.

16. Lathioor, E. C.; Leigh, W. J.; Photochem. Photobiol. 2006, 82, 291.

17. Boscá, F.; Marín, M. L.; Miranda, M. A.; Photochem. Photobiol. 2001, 74, 637.

18. Quintero, B.; Miranda, M. A.; Ars Pharm. 1998, 41, 27.

19. Miranda, M. A.; Castell, J. V.; Hernández, D.; Gómez-Lechón, M. J.; Boscá, F.; Morera, I. M.; Sarabia, Z.; Chem. Res. Toxicol. 1998, 11, 172 .

20. Boscá, F.; Miranda, M. A.; J. Photochem. Photobiol., B 1998, 43,1 .

21. Lhiaubet-Vallet, V.; Sarabia, Z.; Hernández, D.; Castell, J. V.; Miranda, M. A.; Toxicol. in Vitro 2003, 17, 651.

22. Cadet, J. ; Berger, M. ; Douki, T. ; Ravanat, J. L.; Rev. Physiol. Biochem. Pharmacol. 1997, 131, 1.

23. Lhiaubet, V. ; Paillous, N. ; Chouini-Lalanne, N.; Photochem. Photobiol. 2001, 74, 670. 24. Chouini-Lalanne, N. ; Defais, M. ; Paillous, N.; Biochem. Pharmacol. 1998, 55, 441.

25. Sortino, S.; Condorelli, G.; De Guidi, G.; Guiffrida, S.; Photochem. Photobiol. 1998, 68, 652.

26. Lahoz, A. ; Hernández, D.; Miranda, M. A.; Pérez-Prieto, J. ; Morera, I. M. ; Castell, J. V.; Chem. Res. Toxicol. 2001, 14, 1486.

27. Miranda, M. A. ; Pérez-Prieto, J. ; Lahoz, A. ; Morera, I. M. ; Sarabia, Z. ; Martinez-Mañez, R.; Castell, J. V. ; Eur. J. Org. Chem. 1999, 497.

28. Pérez-Prieto, J.; Boscá, F.; Galian, R. E.; Lahoz, A.; Domingo, L. R.; Miranda, M. A.; J. Org. Chem. 2003, 68, 5104.

29. Nakazumi, H. ; Ueyama, T. ; Kitao, T.; J. Heterocycl. Chem. 1985, 22, 1593.

30. Nakib, T. A.; Bezijiak, V.; Meegan, M. J.; Eur. J. Med. Chem. 1990, 25, 455 . 
31. Liu, Y.; Luo, W.; Sun, L.; Guo, C.; Drug Discov. Ther. 2008, 2,216

32. Turro, N. J.; Ramamurthy, V.; Scaiano, J. C.; Principles of Molecular Photochemistry - An Introduction, University Science Books: California, 2009.

33. Loutfyi, R.; Still, I. W. J.; Thompson, M.; Leong, T. S.; Can. J. Chem. 1979, 57, 638.

34. Couture, A.; Lablache-Combier, A.; Min, T. Q.; Tetrahedron Lett. 1977, 2873.

35. Bensasson, R.; Land, E. J.; Mavdinas, B.; Photochem. Photobiol. 1976, 23, 189.
36. Kumar, C.V.; Chattopadhay; Das, P. K. ; J. Am. Chem. Soc. 1983, 105, 5143.

37. Stern, O.; Volmer, M.; Physik. Z. 1919, 20, 183.

38. Scaiano, J. C.; Encinas, M. V.; J. Am. Chem. Soc. 1981, 103, 6393.

39. Hammett, L. P.; J. Am. Chem. Soc. 1937, 59, 96.

40. Hammett, L. P.; Trans. Faraday Soc. 1938, 34, 156.

41. Shukla, D.; Schepp, N. P.; Mathivan, N.; Johnston, L. J.; Can. J. Chem. 1997, 75, 1820.

Received: October 13, 2009 Web Release Date: March 11, 2010 